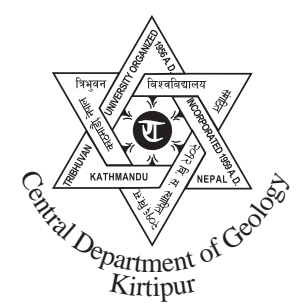

\title{
Fluvial morphology and sediment transport of the Malekhu Khola, Central Nepal Lesser Himalaya
}

\author{
Niraj Bal Tamang, *Naresh Kazi Tamrakar, Milan Magar and Mahesh Raut \\ Central Department of Geology, Tribhuvan University, Kathmandu, Nepal
}

\begin{abstract}
Areas near the rivers and streams have been widely used for settlement, development works and agriculture due to availability of the resources such as water, aggregates and comparatively easier terrain. It is very important to understand prevailing fluvial conditions for sustainable output. The fluvial conditions of the Malekhu Watershed including the river characteristics, sediment transport and sediment dynamics were studied. Ten river transects and the corresponding segments of the Malekhu Khola were surveyed for cross-sections and longitudinal profiles. Samples were collected in each of the transects and were analysed for suspended sediment concentration. The riverbed sampling was made using Wolman's pebble count for establishing grain size distribution. Manning's roughness coefficients were determined to estimate discharge. The study shows that the Malekhu Khola is a sixth order stream. It has been classified into A4-, B4- and C4-type streams. The hypsometric analysis of the Malekhu Watershed shows that it is in mature stage of erosion. Sediment grain size slightly increases downstream but sorting remains extremely poor to moderately poor. The Malekhu Khola shows eroding tendency at $1.2 \mathrm{~km}, 16.6 \mathrm{~km}$ and $20 \mathrm{~km}$ from the origin and brings larger particles only during high flow period at the remaining transects. Mean Suspended Sediment Concentrations (SSC) for the Malekhu Khola was $72.14 \mathrm{mg} / \mathrm{L}$, and it increases with increasing discharge and increasing watershed area and is related to velocity of the river, mining activities and local tributaries.
\end{abstract}

Key words: Fluvial morphology, hydraulic parameters, hypsometric integral, sediment load, central Nepal

Received: 5 March, 2015

Accepted: 4 June, 2015

\section{INTRODUCTION}

In the Central Nepal Lesser Himalaya particularly in monsson season, flooding, erosion, landsliding, etc. occurring in the river basin cause loss of life and property. Streams are dynamic systems that balance water flow and sediment transport. It is known that sediments in the river have their origin from different sources. Therefore, the proportion that each source contributes to the mix varies over time and space, as a result of erosion that is ongoing in the basin of contribution (Poleto et al., 2009). Furthermore, erosion and sedimentation exacerbate the instability of the river channel. This is why it is better to have more

\footnotetext{
*Corresponding author:

E-mail address: ntamrakar@hotmail.com
}

information regarding river; sediment transport, discharge, and dynamics.

Topography, rainfall condition, terrain materials, stream characteristics and landuse play a significant role in the nature and amount of erosion. Singh and Sarangi (2009) performed an assessment of erosion status of two watersheds through hypsometric analysis and highlighted the use of this analysis in interpreting the watershed health condition in terms of erosion. The first attempt to the formulation of a rational theory of bed load transport was made by Du Boys (1879) when he postulated that the bed load discharge should be a function of the difference between the bed shear stress and critical shear stress of the sediment particles in the bed. Understanding of river dynamism and its related processes, and river stability condition are very 
important for watershed management, wetland management, flooding mitigation, sedimentation management and sustainable development of infrastructures (Shrestha and Tamrakar, 2012). Tamrakar and Shrestha (2008) suggested that rivers originating from the Lesser Himalaya with unstable slope are even more capable to flush out sediment compared to the rivers of the Siwaliks. This paper aims to give fluvial morphology, and dynamic scenario of sediment transport by the Malekhu Khola, which lies in the Dhading District of the Central Nepal Lesser Himalaya (Fig. 1).

\section{GEOLOGICAL SETTING}

Geology of the study area is based on the work of Stöcklin (1980) and the present survey along the Malekhu Khola section. The Malekhu area lies on the rocks of the Lesser Himalaya, comprising the autochthonous Upper Nawakot Group of the Nawakot Complex, and the Bhimphedi Group and the Tistung Formation (of the Phulchauki Group) of the allochthonous Kathmandu Complex. There is a massive granite intrusion (Agra Granite) in the Tistung Formation of the Phulchauki Group (Table 1; Fig. 2).

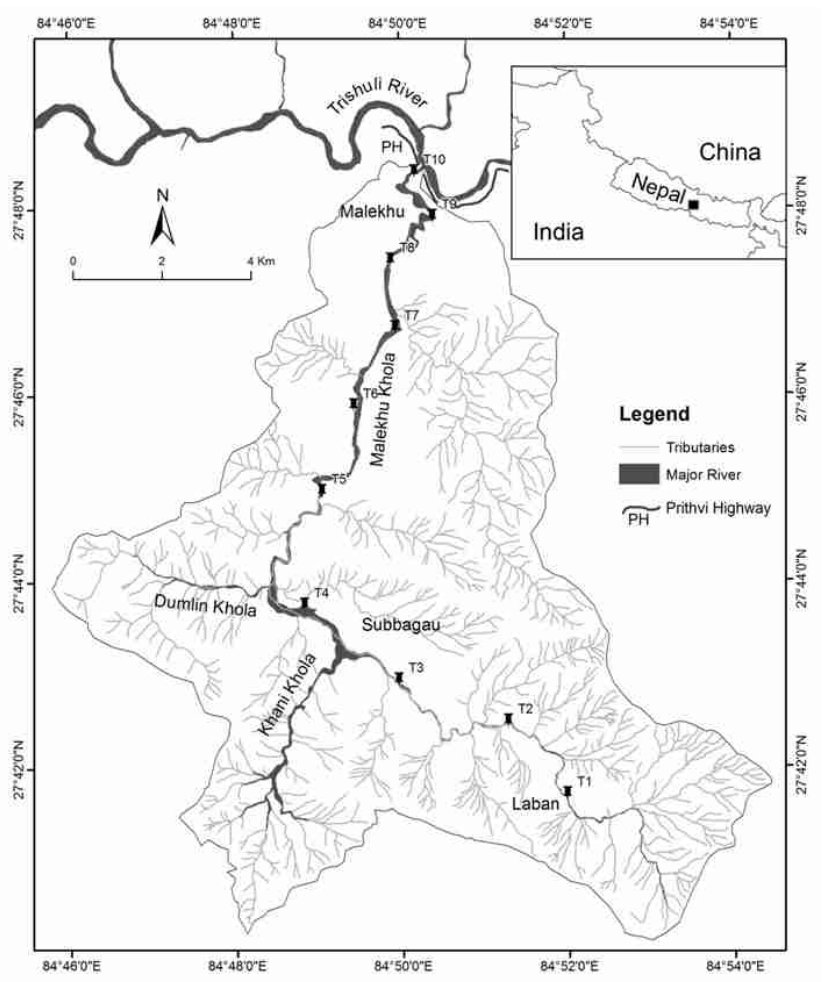

Fig. 1 Location map of the study area
The Nawakot Complex comprises the Lower and the Upper Nawakot Groups. The Nawakot complext consists almost exclusively of low-grade metasedimentary rocks. The Kathmandu Complex has been divided into the Precambrian Bhimphedi Group (Nadgir et al. 1968-73), consisting of relatively highgrade metasedimentary rocks, and the Phulchauki Group of sedimentary and weakly metamorphosed rocks of Early-Middle Palaeozoic age. The Mahabharat Thrust passes across the Malekhu Khola separating the Nawakot Complex to the north with the Kathmandu Complex to the south. The dominant structural feature is the large, WNW-ESE trending Mahabharat synclinorium, a doubly plunging megafold with steep flanks, a well-developed western closure and a narrow, elongated eastern wing (Stöcklin, 1980).

\section{METHODOLOGY}

The fluvial morphology and sediment transport were included in the study. The fluvial morphology was studied in watershed-scale and reach scale levels. The watershed-scale parameters included stream order, planform, and hypsometric integral. Stream order was identified using Strahler's (1957; 1969) method. Planform of the Malekhu Khola was measured using a toposheets (1:25, 000 scale).

\section{Watershed-scale Analysis}

The hypsometric integral (HI) is a geomorphological parameter classified under the geologic stages of watershed development. It assumes importance in estimation of erosion status of watershed and subsequent prioritization for taking up soil and water conservation activities. The hypsometric integral is also an indication of the 'cycle of erosion', i.e., time required for reduction of a landtopological unit to the base level (Strahler 1952; Garg 1983). This entire period or the 'cycle of erosion' can be divided into three stages viz. old $(\mathrm{HI}<0.3)$, in which the watershed is fully stabilized; equilibrium or mature stage $(0.3=\mathrm{HI}=0.6)$; and inequilibrium or young stage (HI>0.6), in which the watershed is highly susceptible to erosion (Strahler 1952).

For the hypsometric analysis, the subwatershed map along with the DEM of the Malekhu Khola Watershed 
Fluvial morphology and sediment transport of the Malekhu Khola, Central Nepal Lesser Himalaya

Table Lithostratigraphy of the Geology of the Lesser Himalaya (after Stöcklin, 1980)

\begin{tabular}{|c|c|c|c|c|c|}
\hline Complex & Group & Formation & Main lithology & $\begin{array}{l}\text { Thickness } \\
\text { (m) }\end{array}$ & Age \\
\hline \multirow{11}{*}{ 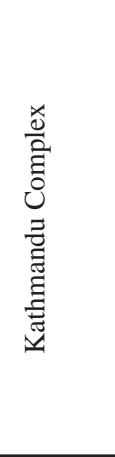 } & \multirow[t]{5}{*}{ Phulchauki } & Godawari Limestone & Limestone & $300-400$ & Devonian \\
\hline & & Chitlang Formation & Slate, Quartzite & 1000 & Silurian \\
\hline & & Chandragiri Limestone & Limestone & 2000 & Cambrian \\
\hline & & Sopyang Formation & Slate, calc. Phyllite & 200 & Cambrian (?) \\
\hline & & Tistung Formation & Metasandstone, Phyllite & 300 & $\begin{array}{l}\text { Early Cambrian or } \\
\text { Late Precambrian }\end{array}$ \\
\hline & \multirow[t]{6}{*}{ Bhimphe } & Markhu Formation & Marble, schist & 1000 & Late Precambrian \\
\hline & & Kulekhani Formation & Quartzite, schist & 2000 & Precambrian \\
\hline & & Chisapani Quartzite & White quartzite & 400 & Precambrian \\
\hline & & Katitar Formation & Quartzite, schist & 2000 & Precambrian \\
\hline & & Bhainsedobhan Marble & Marble & 800 & Precambrian \\
\hline & & Raduwa Formation & Garnetiferous schist & 1000 & Precambrian \\
\hline & …… & .Mahabharat T & 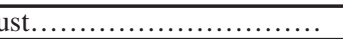 & & \\
\hline \multirow{9}{*}{ 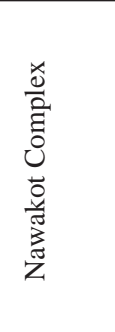 } & Upper & Robang Formation & Phyllite, Quartzite & $200-1000$ & Early Paleozoic \\
\hline & Nawakot & Malekhu Limestone & Limestone, Dolomite & 800 & Early Paleozoic \\
\hline & Group & Benighat slate & Slate, argillaceous dolomite & $500-3000$ & Early Paleozoic \\
\hline & \multicolumn{5}{|c|}{ Unconformity } \\
\hline & Lower & Dhading Dolomite & Stromatolitic dolomite & $500-1000$ & Precambrian \\
\hline & Nawakot & Nourpul Formation & Phyllite, Metasandstone & 800 & Precambrian \\
\hline & Group & DandagaunPhyllite & Phyllite & 1000 & Precambrian \\
\hline & & Fagfog Quartzite & White Quartzite & 400 & Precambrian \\
\hline & & Kuncha Formation & Phyllite, Quartzite & 3000 & Precambrian \\
\hline
\end{tabular}

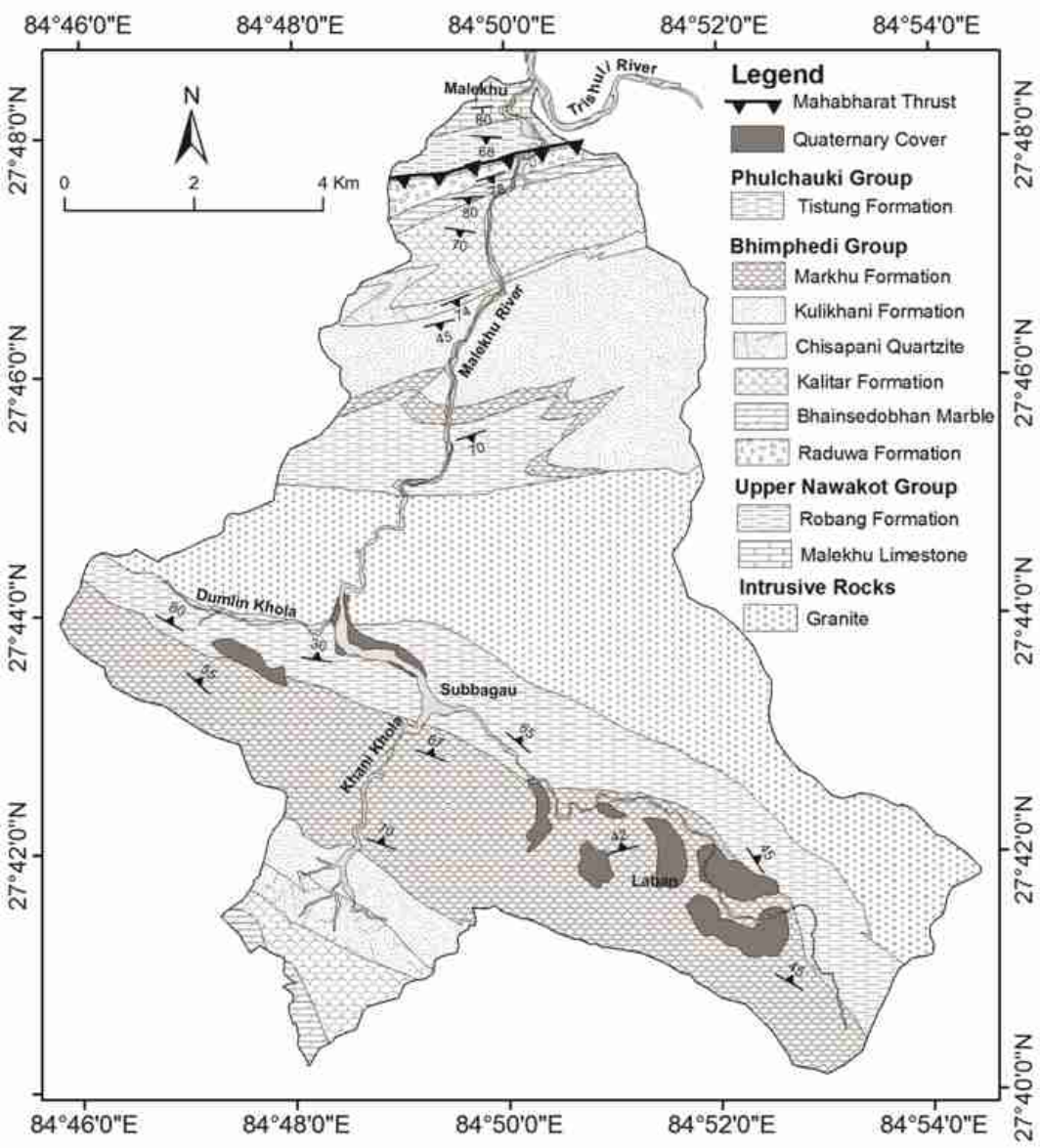

Fig. 2 Geological map of the study area 
was prepared in GIS. Then, normalized elevation $(\mathrm{h} / \mathrm{H})$ was plotted against the percent area $(\mathrm{a} / \mathrm{A})$ for each subwatershed to obtain the hypsometric curve. The hypsometric integral (HI) was obtained by using the following formula proposed by Pike and Wilson (1971):

HI=(Elv.mean-Elv.min.)/(Elv.max.-Elv.min.)...(1)

\section{Reach-scale Analysis}

Cross-section surveys were carried out to generate hydraulic data. Longitudinal profiles were measured for slope. To characterize grain size of each of ten segments in reach-scale and in cross-section scale, Wolman's (1954) pebble counting was adopted. The stream segments were classified into different types designated by Rosgen (1994). Different hydraulic parameters at each trasect were plotted against the bankfull area and the subwatershed area contributing upto the transect considered.

The calculation of rate of bed load for the Malekhu Khola was made using the Hassanzadeh (2007) type of common dimensionless formulae on the hydraulics of sediment transport. The existing relations were used to determine the rate of bedload in volume per unit width and unit time (qs), and rate of bedload in weight per unit time (Qs). The variables calculated and used in formula are listed in Table 2.

After the calculation of the rate of bedload in volume per unit width and unit time (qs), the rate of bedload in weight per unit time (Qs) was calculated using following formula:

$$
\mathrm{Qs}=\gamma_{\mathrm{s}} \mathrm{W}_{\mathrm{bkf}} \mathrm{qs} 80 \text {. }
$$

Where, $\mathrm{W}_{\mathrm{bkf}}$ is the Bankfull width, $\gamma_{\mathrm{s}}$ is solid particle specific weight.

Most of the suspended sediment concentration (SSC) in a river is due to erosion on the watershed and is not made up of bed material. SSC quantifies concentrations of suspended solid material in surface water. It is usually expressed in milligrams per liter (mg/L). SSC was measured after ASTM D3977-79 (2002) by filtration of a litre of sample, and obtaining the dry weight of all the sediment from a known volume of a water-sediment mixture.

\section{RESULTS}

\section{Morphometry}

The Malekhu Khola is a $24.83 \mathrm{~km}$ long sixth-order stream (Table 3; Fig. 3) and has the watershed area of $101.28 \mathrm{~km}^{2}$. The sixth order of the Malekhu Khola is the longest section of length of $11.49 \mathrm{~km}$ and also covers largest watershed area of $70.28 \mathrm{~km}^{2}$.

\section{Hypsometric Intregal (HI)}

Table 2: Dimensionless existing formula to calculate bedload rate (after Hassanzadeh, 2007)

\begin{tabular}{|c|c|}
\hline Formula & Explanation \\
\hline $\begin{array}{l}\text { Einstein-Brown } \\
\text { (1947) }\end{array}$ & $\begin{array}{l}\text { Where, } a=\text { Immersed sediment specific gravity, } \\
\qquad a=\left(\gamma_{\mathrm{s}}-\gamma\right) \gamma \\
\mathrm{f}=\text { hydrodynamic-immersed gravity force ratio, } \\
\mathrm{f}=\left\{\gamma \mathrm{R}_{\mathrm{h}} \mathrm{S} /\left(\gamma_{\mathrm{s}}-\gamma\right) \mathrm{d}\right\}\end{array}$ \\
\hline $\begin{array}{l}\text { Bonnefille } \mathrm{qs} /\left(\left(\operatorname{agd}^{3}\right)\right)^{0.5}=5.5 \mathrm{f}^{1.5}\left(4.26 \mathrm{f}^{0.5}-1\right)^{1.25} \\
(1963)\end{array}$ & $\begin{array}{l}\gamma=\text { liquid specific weight } 1000 \mathrm{~kg} / \mathrm{m}^{3} \\
\gamma_{\mathrm{s}}=\text { solid particle specific weight } 2650 \mathrm{~kg} / \mathrm{m}^{3}\end{array}$ \\
\hline $\mathrm{qs} /\left(\left(\operatorname{agd}^{3}\right)\right)^{0.5}=24 \mathrm{f}^{2.5}$ & $\begin{array}{l}\mathrm{R}_{\mathrm{h}}=\text { hydraulic radius }(\mathrm{m}) \\
\mathrm{S}=\text { bed slope }(\mathrm{m} / \mathrm{m}) \\
\mathrm{d}=\text { particle diameter }\left(\mathrm{d}_{50} \mathrm{in} \mathrm{m}\right)\end{array}$ \\
\hline
\end{tabular}


Table 3: Stream order, length and subwatershed area of the main stem of the Malekhu Khola

\begin{tabular}{lccccccc}
\hline Stream order & 1 & 2 & 3 & 4 & 5 & 6 & Total \\
\hline Length $(\mathrm{km})$ & 0.35 & 1.16 & 2.59 & 6.32 & 2.92 & 11.49 & 27.83
\end{tabular}

$\begin{array}{llllllll}\text { Subwatershed } & 0.03 & 0.42 & 2.35 & 21.30 & 6.90 & 70.28 & 101.28\end{array}$ area $\left(\mathrm{km}^{2}\right)$

There are altogether 91 first order, 20 second order, 27 third order, 3 fourth order and 1 fifth order subwatershed in the whole Malekhu Khola Watershed. The main stem becomes fifth ordered Strahler's stream order classification basis) when it reaches Talti where it meets the Khani Khola and becomes sixth order river. There are 14 subwatersheds which have HI less than $0.3,116$ subwatersheds which have HI between 0.3 to 0.6 and 12 subwatersheds which have HI greater than 0.6. The first order subwatersheds within the Malekhu Khola Watershed have HI value ranging from 0 to 0.71 (Table 4) while second order subwatersheds have HI ranging from 0.223 to 0.620 . The third order subwatersheds have HI ranging from 0.282 to 0.691 and

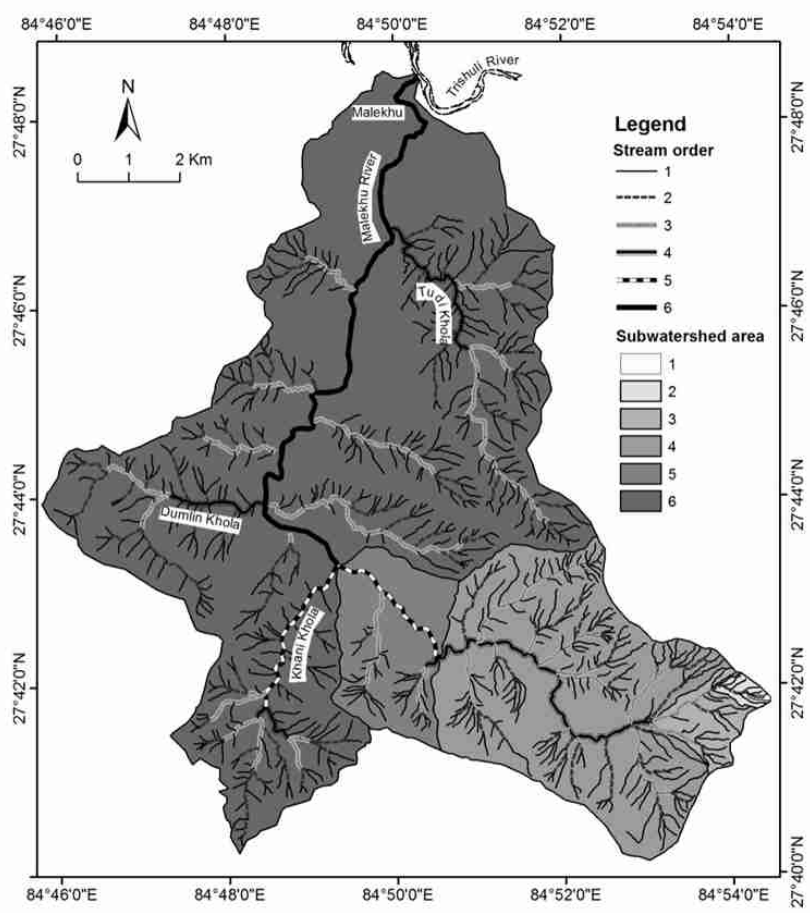

Fig. 3 Stream order and subwatershed map for the main stem and major tributaries of the Malekhu Khola the fourth order subwatersheds have HI ranging from 0.265 to 0.586 . The majority of the subwatersheds are in mature stage (Fig. 4) including the Tudi Khola, Reti Khola, Khahare Khola and Dhobi Khola subwatershed while some of the major tributaries of the Malekhu Khola such as the Khani Khola and Dumlin Khola are in monandnock stage. Some of the subwatersheds in the upstream sections are young in nature and have high erosion characteristics.

\section{Stream Morphology}

Table 4: Hypsometric Integral values for the first, second, third and fourth subwatershed of the Malekhu Khola Watershed.

\begin{tabular}{ccccc}
\hline \multirow{2}{*}{$\begin{array}{c}\text { Subwatershed } \\
\text { Order }\end{array}$} & Min. & Max. & Mean & STDEV \\
\hline 1 & 0 & 0.71 & 0.459 & 0.114 \\
2 & 0.223 & 0.62 & 0.402 & 0.112 \\
3 & 0.282 & 0.691 & 0.463 & 0.104 \\
4 & 0.265 & 0.586 & 0.389 & 0.172 \\
\hline
\end{tabular}

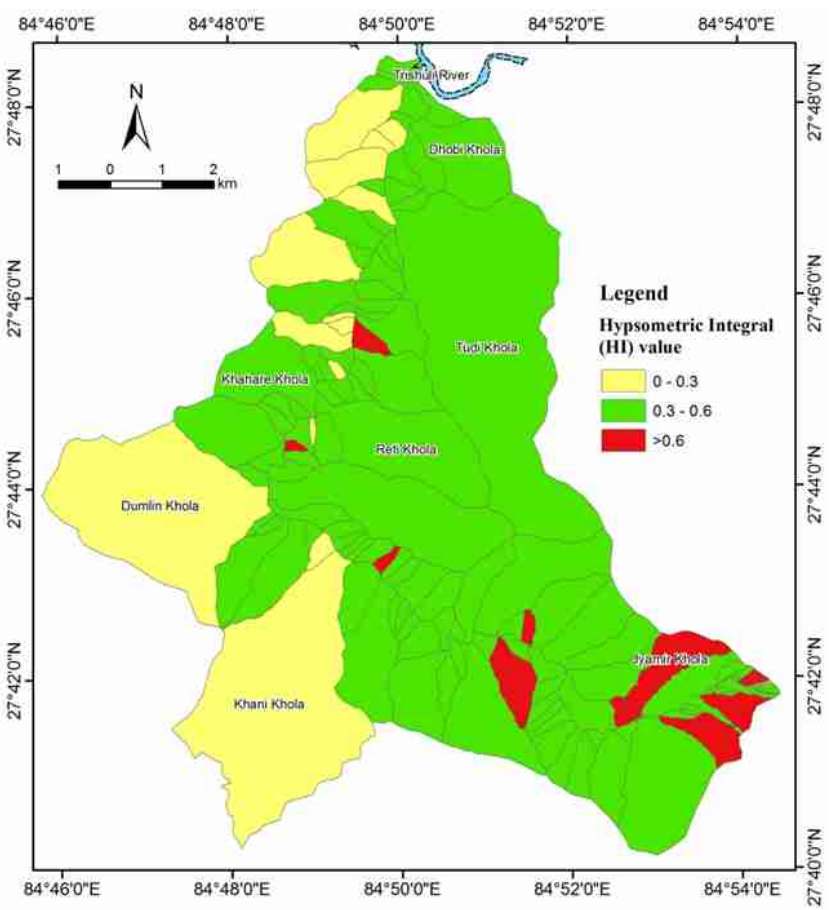

Fig. 4 Hypsometric map of the MalekhuKhola Watershed 
Sinuosity (K) ranges from 1.06 to 1.51 (Table 5). T4 and $\mathrm{T} 8$ have low sinuosity $(\mathrm{K}=1.06)$. This low value of sinuosity indicates that they have very high eroding potential. $\mathrm{T} 5$ has the highest value of sinuosity $(\mathrm{K}=1.51)$ indicating matured and meandering segment compared to other transects. The meander wavelength ranges from 0.231 to $0.850 \mathrm{~km}$, and the meander belt width ranges from 0.15 to $0.725 \mathrm{~km}$. Both $\mathrm{Lm}$ and $\mathrm{W}_{\mathrm{blt}}$ increase with increasing stream order.

The Malekhu Khola profile is concave upward in shape (Fig. 5). Stream with a steep slope has low sinuosity whereas stream with a gentle slope has high sinuosity. Although slope is partly imposed by geological constraints, streams are nevertheless free to change slope substantially by means of aggradation and degradation.

The Malekhu Khola reaches have been classified as A4-, B4- and C4-type streams (Table 6). A4- and B4type streams are moderate-gradient gravelly and low sinuosity rivers whereas C4-type streams are lowgradient gravelly meandering river. The Malekhu Khola gradually changes from A4- to B4-type streams up to $12 \mathrm{~km}$ downstream, and then to C4-type stream further downstream, but B4-type streams reappear within the distance of $15 \mathrm{~km}$ to $19 \mathrm{~km}$ from the origin.

The observed lithofacies on various sedimentary environmental elements are summarized in Table 7. Almost all the trasects have dominantly of gravel lithofacies.

\section{Morpho-hydraulic Parameters}

The morpho-hydraulic parameters such as bankfull area, bankfull width, bankfull depth, width-depth ratio, floodprone width, entrenchment ratio, wetted perimeter, hydraulic radius, slope, Manning's n-value, bankfull discharge and bankfull velocity were measured and calculated in field (Table 8). Bankfull cross-sectional area $\left(\mathrm{A}_{\mathrm{bkf}}\right)$ of a stream is the area covered by water during bankfull flow. Bankfull width is the horizontal distance between right and left bankfull point which is measured in field. Entrenchment Ratio (ER) is the ratio of flood prone width to bankfull width. A stream is said

Table 5: Planform parameters of the main stem of the Malekhu Khola

\begin{tabular}{lcccccccccc}
\hline Transects & T1 & T2 & T3 & T4 & T5 & T6 & T7 & T8 & T9 & T10 \\
\hline Sinuosity $(\mathrm{K})$ & 1.08 & 1.15 & 1.27 & 1.06 & 1.51 & 1.22 & 1.08 & 1.07 & 1.06 & 1.44 \\
Rc $(\mathrm{km})$ & 0.18 & 0.27 & 0.16 & 0.42 & 0.17 & 0.31 & 0.51 & 0.36 & 0.07 & 0.16 \\
Lm $(\mathrm{km})$ & 0.68 & 0.44 & 0.34 & 0.76 & 0.42 & 0.85 & 0.84 & 0.62 & 0.23 & 0.51 \\
$\mathrm{~W}_{\text {blt }}(\mathrm{km})$ & 0.28 & 0.15 & 0.15 & 0.45 & 0.53 & 0.23 & 0.5 & 0.33 & 0.73 & 0.43 \\
$\mathrm{~W}_{\text {bkf }}(\mathrm{m})$ & 11.0 & 10.0 & 20.0 & 30.0 & 17.5 & 30.0 & 18.3 & 22.3 & 32.0 & 23.0 \\
MLR & 0.06 & 0.04 & 0.02 & 0.03 & 0.02 & 0.03 & 0.05 & 0.03 & 0.01 & 0.02 \\
MWR & 0.03 & 0.02 & 0.01 & 0.02 & 0.03 & 0.01 & 0.03 & 0.02 & 0.02 & 0.02 \\
\hline
\end{tabular}

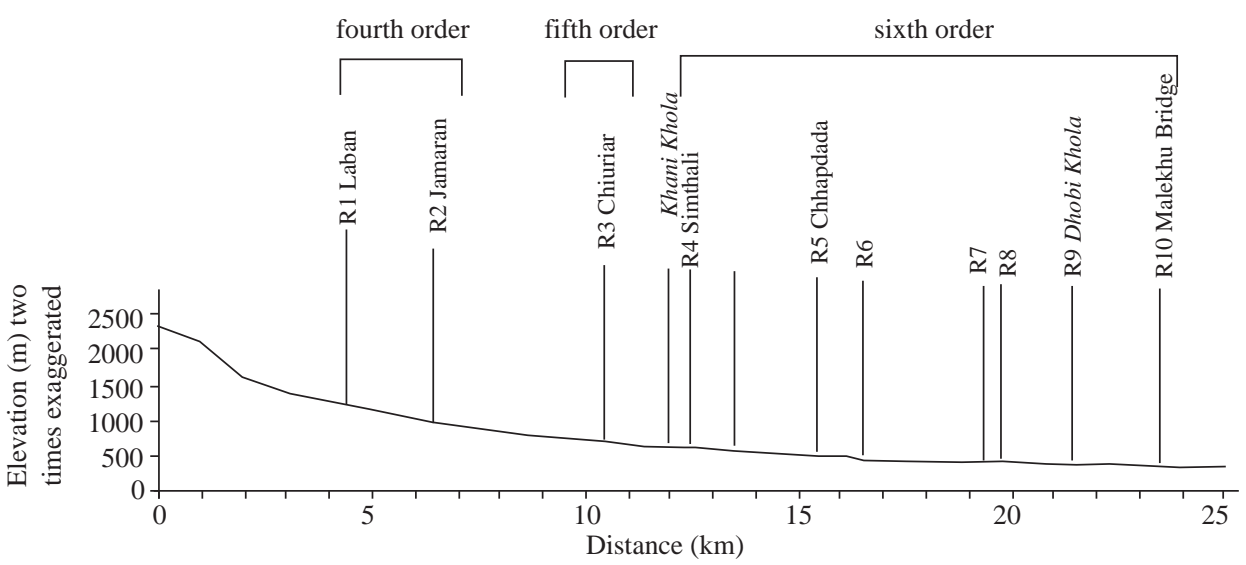

Fig. 5 Longitudinal section of the main stem of the Malekhu Khola 
Fluvial morphology and sediment transport of the Malekhu Khola, Central Nepal Lesser Himalaya

Table 6: Level II classification of the Malekhu Khola

\begin{tabular}{clclc}
\hline Transect & Location & Stream Order & Geological Formation & Stream Type \\
\hline 1 & Laban & 4 & Markhu Formation & A4 \\
2 & Jamaran & 4 & Markhu Formation & A4 \\
3 & Cheuritar & 5 & Tistung Formation & B4 \\
4 & Simthali & 6 & Tistung Formation & C4 \\
5 & Chhapdada & 6 & Granite Intrusion & B4 \\
6 & Kajitol & 6 & Kulikhani Formation & B4 \\
7 & Dwarephat & 6 & Kulikhani Formation & C4 \\
8 & Mawatar & 6 & Kalitar Formation & C4 \\
9 & Dhobi Khola Confluence & 6 & Robang Formation & $\mathrm{C} 4$ \\
10 & Malekhu Bridge & 6 & Malekhu Limestone & $\mathrm{C} 4$ \\
\hline
\end{tabular}

Table 7: Major lithofacies obeserved along Malekhu Khola at ten different transects

\begin{tabular}{|c|c|c|}
\hline Transect & Lithofacies & Remarks \\
\hline $\mathrm{T} 1$ to $\mathrm{T} 2$ & Channel- cobG, Floodplain-pcobG & $\begin{array}{l}\text { Large boulders (b-axis approx } 3 \mathrm{~m} \text { ) of granite distributed on the main channel, } \\
\text { Large angular boulders in floodplain, Presence of large boulders near the } \\
\text { channel and reduction of grain size further downstream from the main channel, } \\
\text { sparse vegetation on floodplain. }\end{array}$ \\
\hline $\mathrm{T} 2$ to $\mathrm{T} 3$ & Channel-pcoG & $\begin{array}{l}\text { Thickness of floodplain is about } 8 \mathrm{~cm} \text { in some exposed part and in some area } \\
\text { upto } 1.5 \mathrm{~m} \text {. Though the floodplain consists of significant amount of boulders and } \\
\text { cobbles, it has some area with fine-grained sediments as silt and some clay on } \\
\text { its top part. Floodplain is used for agricultural purposes. }\end{array}$ \\
\hline $\mathrm{T} 3$ to $\mathrm{T} 4$ & $\begin{array}{l}\text { Channel- pcoG and bcoG, } \\
\text { Floodplain-cobG, bcopG and pcobG }\end{array}$ & $\begin{array}{l}\text { Effect of the Khani Khola on the lithofacies of channel sediment and floodplain } \\
\text { is significant. In some exposed part of the floodplain the thickness is as much as } \\
1 \mathrm{~m} \text { near Chiuritar. The thickness of the floodplain increases and reaches upto } 2 \\
\mathrm{~m} \text { in exposed part about } 150 \mathrm{~m} \text { downstream from the confluence. }\end{array}$ \\
\hline $\mathrm{T} 4$ to $\mathrm{T} 5$ & $\begin{array}{l}\text { Channel- bpcoG and pcoG, } \\
\text { Floodplain- pcobG and cobG, Mid- } \\
\text { channel bar- pcoG, Point bar- pcobG }\end{array}$ & $\begin{array}{l}\text { Thickness of floodplain is about } 1 \text { to } 1.5 \mathrm{~m} \text { in exposed part. Presence of } \\
\text { vegetation on some part of the floodplain while most part was barren with small } \\
\text { bushes. }\end{array}$ \\
\hline
\end{tabular}

T5 to T6 Channel- copG, Floodplain- pcobG and pcoG, Mid-channel bar- bpcoG and pcoG

Thickness of floodplain was about $1 \mathrm{~m}$ in some exposed part.The vegetation was more on the farthest part of floodplain from main river channel.It was observed that the amount of boulder has been diminished in this region.

T6 to T7 Channel- copG, Floodplain- pcoG Presence of dense vegetation on floodplain. Presence of well sorted sediments and copS, Point bars- pcoG and pS. on point bars. Thickness of point bar is about $2 \mathrm{~m}$.

T7 to T8 Channel- bpcoG, Floodplain- bcopG Floodplain consists of alternative mud layer and sand layer which are thicker and pcosG, Natural Levee- scoG near the channel. The bottom part of the floodplain consists of coarse sediments. Presence of low amount of fine sands on the river bed. Natural levee consists of coarsening upward sequence.

T8 to T9 Channel- scopG, Floodplain- pcoS Sizes of boulder range from 0.50 to $2 \mathrm{~m}$. and bcopS, Point bar- bcopG, Natural Levee- scoG.

T9 to T10 Channel- pcobS, Floodplain- cobG, Presence of chute channel in some upper portions of point bars. The floodplain pcogS, pcoG, copS and scopG. consists of dispersed coarse-grained sediments such as cobble and boulders probably derived during debris flow. 
to be entrenched if the value of entrenchment ratio is less than 1.4 and stream having higher than 1.4 shows affinity to flooding (Rosgen, 1994). Slope of the stream is the ratio of elevation difference to distance of river. Manning's roughness coefficient (n) depends on the different factors such as channel irregularity, surface roughness, vegetation, seasonal change, channel materials, suspended material, bed material (Cowan, 1956). Due to the lack of the gauge station, velocity (V) and discharge $(\mathrm{Q})$ of the Malekhu Khola were estimated through the Manning's equation and continuity equation (Chow,1959), respectively as:

$$
\begin{aligned}
& \mathrm{V}=\left(\mathrm{R}^{2 / 3} \cdot \mathrm{S}^{1 / 2}\right) / \mathrm{n} \\
& \mathrm{Q}=\mathrm{V} \cdot \mathrm{A}_{\mathrm{bkf}} \ldots \ldots \ldots \ldots
\end{aligned}
$$

where, $\mathrm{R}$ is hydraulic radius (m), $\mathrm{S}$ is average channel slope $(\mathrm{m} / \mathrm{m}), \mathrm{n}$ is Manning's roughness coefficient, $A_{b k f}$ is the cross-sectional area $\left(m^{2}\right)$. $R$ is the ratio of $A_{b k f}$ to wetted perimeter.

The values of the calculated hydraulic parameters (Table 8) are not homogenous for the MRW and their values fluctuate randomly for each transect. Bankfull area is maximum at $\mathrm{T} 9$ and minimum at $\mathrm{T} 2$. W/D ratio is maximum at $\mathrm{T} 4$ and minimum at $\mathrm{T} 1$. Flood prone width is maximum at $\mathrm{T} 8$ and minimum at $\mathrm{T} 2$. Entrenchment ratio is maximum at $\mathrm{T} 8$ and minimum at $\mathrm{T} 2$. Discharge is maximum at $\mathrm{T} 9$ and minimum at $\mathrm{T} 3$.
Most of the maximum values are in downstream sections while most of the minimum values are in upstream sections. The geology and the landuse might also be responsible for such fluctuation.

\section{Grain size analysis}

The grain size was determined as a textural parameter of the sediments (Table 9). Data obtained from Wolman Pebble counting method was used to calculate grain-size parameters (mean, median, and sorting) by a graphical method (Folk and Ward, 1957).

Median is the diameter corresponding to the $50 \%$ mark on the cumulative frequency curve and may be expressed either in phi or in mm. Graphic Mean (M) was calculated from following formula:

$$
\mathrm{M}=(\phi 16+\phi 50+\phi 84) / 3
$$

Sorting is the measure of degree of scatter. It is the tendency for the grains to all is of one class of grain size. It was computed as:

$$
\sigma_{\mathrm{I}}=\{(\phi 84-\phi 16) / 4\}+\{(\phi 95-\phi 5) / 6.6\}
$$

It is observed that the sediments along the Malekhu Khola are are very poorly sorted on its upstream portion (T1-T5), gradually poorly sorted at T6, and moderately

\begin{tabular}{|c|c|c|c|c|c|c|c|c|c|c|}
\hline Transect & 1 & 2 & 3 & 4 & 5 & 6 & 7 & 8 & 9 & 10 \\
\hline $\mathrm{A}_{\mathrm{bkf}}\left(\mathrm{m}^{2}\right)$ & 10.5 & 4.43 & 15.32 & 20.04 & 11.43 & 32.67 & 10.1 & 27.81 & 36.33 & 23.29 \\
\hline $\mathrm{W}_{\mathrm{bkf}}(\mathrm{m})$ & 11 & 10 & 20 & 30 & 17.5 & 30 & 18.3 & 22.3 & 32 & 23 \\
\hline $\mathrm{D}_{\mathrm{bkf}}(\mathrm{m})$ & 0.94 & 0.59 & 0.74 & 0.73 & 0.64 & 1.2 & 0.61 & 1.17 & 0.87 & 1.12 \\
\hline W/D & 11.7 & 17.01 & 27.17 & 41.1 & 27.34 & 25 & 30 & 19.06 & 36.99 & 20.54 \\
\hline $\mathrm{W}_{\mathrm{fpa}}(\mathrm{m})$ & 22 & 17 & 51.5 & 123 & 54.5 & 58 & 38 & 129 & 66 & 72 \\
\hline ER & 2 & 1.7 & 2.58 & 4.1 & 3.11 & 1.93 & 2.08 & 4.96 & 2.06 & 3.13 \\
\hline $\mathrm{WP}(\mathrm{m})$ & 12.88 & 11.18 & 21.47 & 31.46 & 18.78 & 32.4 & 19.52 & 24.64 & 33.73 & 25.32 \\
\hline $\mathrm{R}(\mathrm{m})$ & 0.82 & 0.4 & 0.71 & 0.64 & 0.61 & 1.01 & 0.52 & 1.13 & 1.07 & 0.92 \\
\hline $\mathrm{S}(\mathrm{m} / \mathrm{m})$ & 0.03 & 0.05 & 0.03 & 0.04 & 0.04 & 0.05 & 0.03 & 0.04 & 0.06 & 0.05 \\
\hline n-value & 0.1 & 0.08 & 0.1 & 0.12 & 0.14 & 0.12 & 0.11 & 0.09 & 0.09 & 0.11 \\
\hline $\mathrm{Q}_{\mathrm{bkf}}\left(\mathrm{m}^{3} / \mathrm{s}\right)$ & 16.59 & 6.02 & 4.7 & 22.85 & 11.54 & 62.73 & 9.76 & 69.24 & 97 & 44.25 \\
\hline $\mathrm{V}_{\mathrm{bkf}}(\mathrm{m} / \mathrm{s})$ & 1.58 & 1.36 & 0.31 & 1.14 & 1.01 & 1.92 & 0.97 & 2.49 & 2.67 & 1.9 \\
\hline
\end{tabular}
sorted at $\mathrm{T} 7$. But at $\mathrm{T} 8$ and $\mathrm{T} 9$ the sorting of sediment has drastically changed and it is again very poorly

Table 8: Morpho-hydraulic parameters at different transects along the main stem of the Malekhu Khola 
Table 9: Grain size distribution at different transects along the main stem of the Malekhu Khola.

\begin{tabular}{|c|c|c|c|c|c|c|c|c|c|c|c|c|c|c|c|c|c|c|c|c|}
\hline & \multicolumn{2}{|c|}{$\mathrm{T} 1$} & \multicolumn{2}{|c|}{$\mathrm{T} 2$} & \multicolumn{2}{|c|}{ T3 } & \multicolumn{2}{|c|}{$\mathrm{T} 4$} & \multicolumn{2}{|c|}{ T5 } & \multicolumn{2}{|c|}{ T6 } & \multicolumn{2}{|c|}{$\mathrm{T} 7$} & \multicolumn{2}{|c|}{$\mathrm{T} 8$} & \multicolumn{2}{|c|}{ T9 } & \multicolumn{2}{|c|}{ T10 } \\
\hline & Phi & $\mathrm{mm}$ & Phi & $\mathrm{mm}$ & Phi & $\mathrm{mm}$ & Phi & $\mathrm{mm}$ & Phi & $\mathrm{mm}$ & Phi & $\mathrm{mm}$ & Phi & $\mathrm{mm}$ & Phi & $\mathrm{mm}$ & Phi & $\mathrm{mm}$ & Phi & $\mathrm{mm}$ \\
\hline D5 & -7 & 128 & -8.6 & 512 & -7.8 & 256 & -11 & 2048 & -7.6 & 256 & -8 & 256 & -6 & 64 & -7 & 128 & -8 & 256 & -8.8 & 512 \\
\hline D10 & -6.8 & 128 & -7 & 128 & -7.2 & 128 & -7.8 & 256 & -7 & 128 & -6.2 & 64 & -5.8 & 64 & -6.6 & 128 & -7 & 128 & -7.8 & 256 \\
\hline D16 & -6.6 & 128 & -6 & 64 & -6.2 & 64 & -6.6 & 128 & -6.4 & 64 & -5.8 & 64 & -5.8 & 64 & -6.2 & 64 & -6.6 & 128 & -7.4 & 128 \\
\hline D50 & -5.2 & 32 & -4.8 & 32 & -5 & 32 & -5 & 32 & -5 & 32 & -5 & 32 & -5.2 & 32 & -4 & 16 & -5.6 & 64 & -5.6 & 64 \\
\hline D84 & -1.4 & 2 & -1 & 2 & -2 & 4 & -2 & 4 & -3 & 8 & -3.8 & 16 & -3.8 & 16 & 3.2 & 0.13 & 3.2 & 0.13 & -4 & 16 \\
\hline D95 & 0.8 & 0.5 & 0.6 & 0.5 & 1.6 & 0.25 & -0.8 & 2 & 3 & 0.13 & -2.6 & 8 & -3 & 8 & 3.8 & 0.06 & 3.8 & 0.06 & -3 & 8 \\
\hline $\mathrm{M}_{\mathrm{d}}$ & -5.2 & & -4.8 & & -5 & & -5 & & -5 & & -5 & & -5.2 & & -4 & & -5.6 & & -5.6 & \\
\hline $\mathrm{M}_{\mathrm{z}}$ & -4.4 & & -3.9 & & -4.4 & & -4.5 & & -4.8 & & -4.9 & & -4.9 & & -2.3 & & -3 & & -5.7 & \\
\hline$\sigma_{I}$ & 2.48 & & 2.64 & & 2.47 & & 2.76 & & 2.46 & & 1.32 & & 0.95 & & 3.99 & & 4.24 & & 1.73 & \\
\hline
\end{tabular}

Very well sorted under $<0.35 \phi$; Well sorted 0.35 to $0.50 \phi$; Moderately well sorted 0.50 to $0.71 \phi$; Moderately sorted 0.71 to $1.0 \phi$;

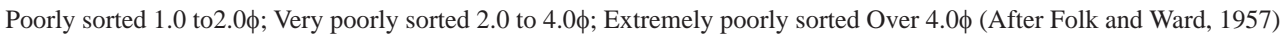

sorted at $\mathrm{T} 8$ and extremely poorly sorted at $\mathrm{T} 9$. At $\mathrm{T} 10$, channel sediment was found to be poorly sorted. This change in sorting of sediment in its downstream should be the effect of anthropogenic factors. Such factor mainly includes the extraction of certain sized material from river channel as a construction material.

The plot between $\mathrm{D}_{5}$ with distance (Fig. 6) shows that the value of $\mathrm{D}_{5}$ slightly decreases with distance. The plot between $\mathrm{D}_{50}$ and distance is observed to change in grain size with distance. It was observed that the maximum grain size occur at $\mathrm{T} 9$ and $\mathrm{T} 10$. The sorting seems to be poorly related to distance of transport.

Boundary shear stress $(\tau)$ and critical shear stress $\left(\tau_{\mathrm{c}}\right)$ at bankfull stage for $\mathrm{d}_{50}$ were obtained using following expressions respectively (Shields, 1936):

$$
\begin{aligned}
& \tau=\gamma \mathrm{RS} \\
& \tau_{\mathrm{c}}=\theta_{\mathrm{c}} \cdot \mathrm{g}\left(\rho_{\mathrm{c}}-\rho\right) \cdot \mathrm{d}_{50}
\end{aligned}
$$

where, $\gamma=$ unit weight of water $\left(9810 \mathrm{~N} / \mathrm{m}^{2}\right), \mathrm{R}=$ hydraulic radius $(\mathrm{m}), \mathrm{S}=$ slope of stream $(\mathrm{m} /), \theta_{\mathrm{c}}=$ Shields parameter for critical dimensionless shear stress which was taken as 0.045 from the Shields Curve for coarse-bedded stream, $g=$ gravitational constant $(9.81$ $\left.\mathrm{m} / \mathrm{s}^{2}\right), \mathrm{d}_{50}=$ median diameter of particle $(\mathrm{m}), \rho_{\mathrm{c}}=$ density of sediment $\left(2650 \mathrm{~kg} / \mathrm{m}^{3}\right), \rho=$ density of water $\left(1000 \mathrm{~kg} / \mathrm{m}^{3}\right)$.

At all transects, boundary shear stress is greater than critical boundary shear stress (Table 9), so the stream is competent enough to carry the bed material distributed on the streambed.
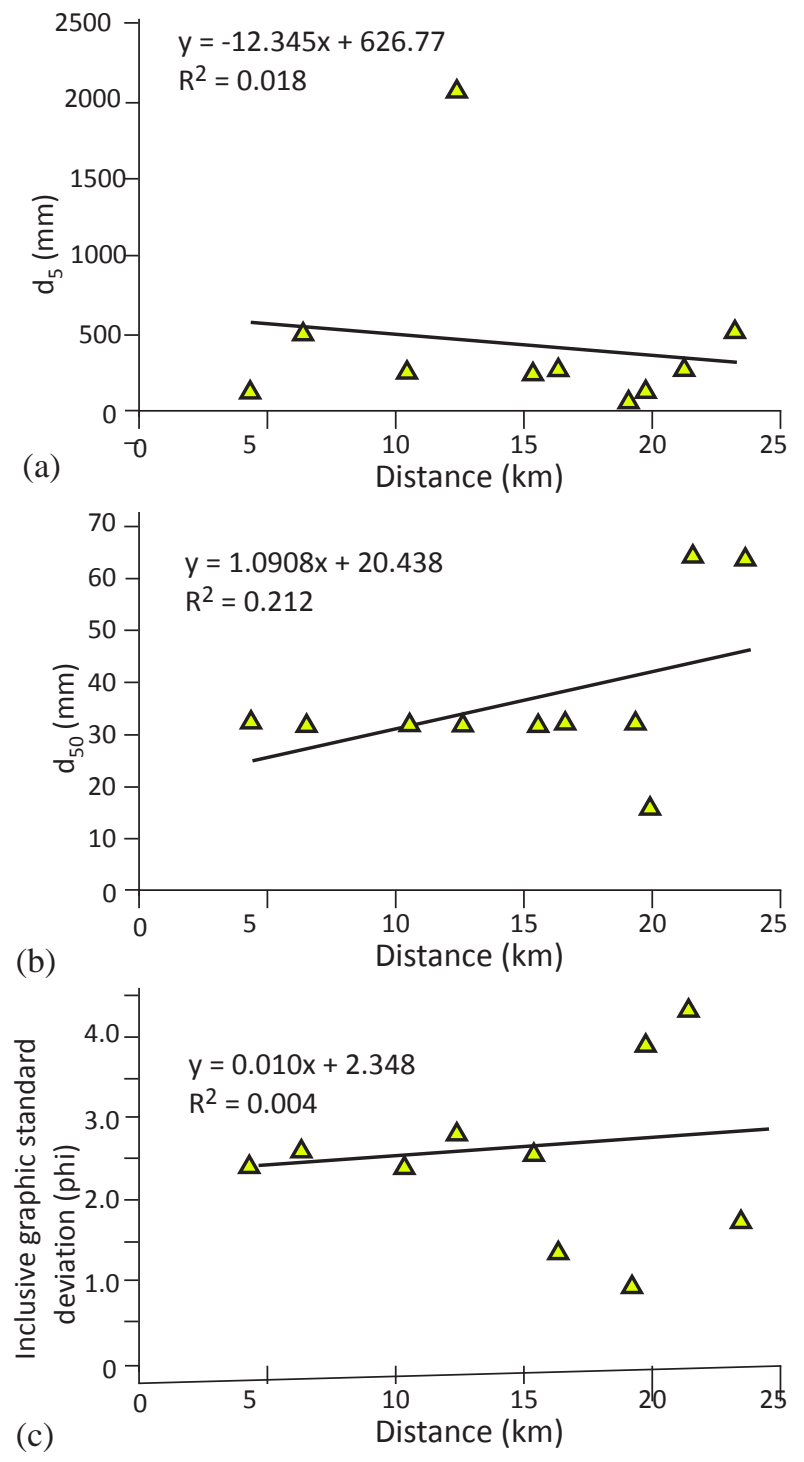

Fig. 6 Grain size parameters against downstream distance. (a) d5 vs. distance, (b) d50 vs. distance, and (c) Inclusive graphic standard deviation vs. distance 
Table 10: Stream competency parameters for the main stem of the Malekhu Khola

\begin{tabular}{lcccccccccc}
\hline \multicolumn{1}{c}{ Transect } & 1 & 2 & 3 & 4 & 5 & 6 & 7 & 8 & 9 & 10 \\
\hline $\mathrm{d}_{50}(\mathrm{~m})$ & 0.06 & 0.06 & 0.02 & 0.03 & 0.03 & 0.03 & 0.03 & 0.03 & 0.03 & 0.03 \\
$\mathrm{~d}_{10}(\mathrm{~m})$ & 0.128 & 0.128 & 0.128 & 0.256 & 0.128 & 0.064 & 0.064 & 0.128 & 0.128 & 0.256 \\
$\tau\left(\mathrm{KN} / \mathrm{m}^{2}\right)$ & 0.241 & 0.196 & 0.209 & 0.251 & 0.239 & 0.495 & 0.153 & 0.443 & 0.629 & 0.451 \\
$\tau_{\mathrm{c} 50}\left(\mathrm{KN} / \mathrm{m}^{2}\right)$ & 0.437 & 0.437 & 0.146 & 0.219 & 0.219 & 0.219 & 0.219 & 0.219 & 0.219 & 0.219 \\
$\tau_{\mathrm{c} 10}\left(\mathrm{KN} / \mathrm{m}^{2}\right)$ & 0.932 & 0.932 & 0.932 & 1.865 & 0.932 & 0.466 & 0.466 & 0.932 & 0.932 & 1.865 \\
$\Omega\left(\mathrm{KNm} / \mathrm{s} / \mathrm{m}^{2}\right)$ & 0.42 & 0.60 & 0.61 & 0.23 & 0.26 & 0.98 & 0.13 & 1.05 & 1.53 & 0.82 \\
\hline
\end{tabular}

Stream power $(\Omega)$ is a measure of the energy transfer (Bagnold, 1966). It is computed by following formula developed by Brookes (1990):

$$
\Omega=\tau \mathrm{V}
$$

where, $\tau=$ boundary shear stress $\left(\mathrm{KN} / \mathrm{m}^{2}\right), \mathrm{V}=$ bankfull velocity $(\mathrm{m} / \mathrm{s})$

The stream power is maximum at $\mathrm{T} 9$ and minimum at T7 (Table 10) along the Malekhu Khola. Since, there is great difference between the boundary shear stress and velocity, the stream power is the function of both boundary shear stress and velocity. The highest value of tractive shear stress at T9 clearly indicates that there is the highest energy or competency to transport bedload. Bedload transport rate obtained from various equations indicates that it is highest at T9. Suspension sediment discharge is also highest at T9. It suggests that the value of tractive shear stress plays an important role in sediment transport. In Malekhu Khola, stream power fluctuates from $0.13 \mathrm{KNm} / \mathrm{s} / \mathrm{m}^{2}$ to $1.53 \mathrm{KNm} / \mathrm{s} / \mathrm{m}^{2}$. Stream power is highest at T9 and lowest at T7. The maximum value at $\mathrm{T} 9$ is due to the increased velocity $(\mathrm{V})$ which is $2.6 \mathrm{~m} / \mathrm{s}$ and boundary shear stress $(0.629$ $\mathrm{KN} / \mathrm{m}^{2}$ ) the lowest value at $\mathrm{T} 7$ is due to the low water velocity $(0.97 \mathrm{~m} / \mathrm{s})$ and boundary shear stress $(0.153$ $\mathrm{KN} / \mathrm{m}^{2}$ ). Stream power shows huge fluctuation along the stream of transporting capacity influenced probably by change in slope and stream pattern.

Based on plots of hyraulic parameters, the relations of bankfull discharge $\mathrm{Q}_{\mathrm{bkf}}$ with bankfull area, bankfull width, $\mathrm{W}_{\mathrm{bkf}}$ and bankfull depth, $\mathrm{D}_{\mathrm{bkf}}$ are established (Figs. 7a, 7b, 7c). These hydraulic geometry relations indicate positive correlation. Among the relationships, one of the bankfull area versus bankfull discharge has better relation among the plots.

In the regional curves (Figs. 7d, 7e, 7f), bankfull discharge, bankfull area and bankfull width have been correlated with the drinage area. These relationships show better relations in exponential function and degree of correlation is almost same. With increasing drainage area, the hydraulic parameters tend to increase in exponential function. This indicates that increase stream bankfull cross-sectional area tends to increase bankfull discharge and bankfull width of the Malekhu Khola.

\section{BedloadTransport}

Sediment transport characteristics when understood benefits many applications including prediction of effects of landuse and flow regime change and channel restoration efforts (Wilcock, 2001). Sediment transport process is a set of phenomena that mediates between the flowing water and the channel boundary. The sediment load of a river is transported as bedload and/or suspended load and/or wash load. Many researches on sediment transport had been made and extension can be found in Vanoni (1984), Yang $(1972 ; 1973)$ and Yallin $(1963 ; 1972)$. The calculation of rate of bed load for the Malekhu Khola was done using the Hassanzadeh (2007) type of common dimensionless formulas on the hydraulics of sediment transport. The existing relations were used to determine the rate of bedload in volume per unit time and unit width (qs) and rate of bedload in weight per unit time (Qs). The rate of bed load (Qs) has though increased (Table 11) from upstream portion of Malekhu Khola towards the downstream portion the trend is fluctuating. 

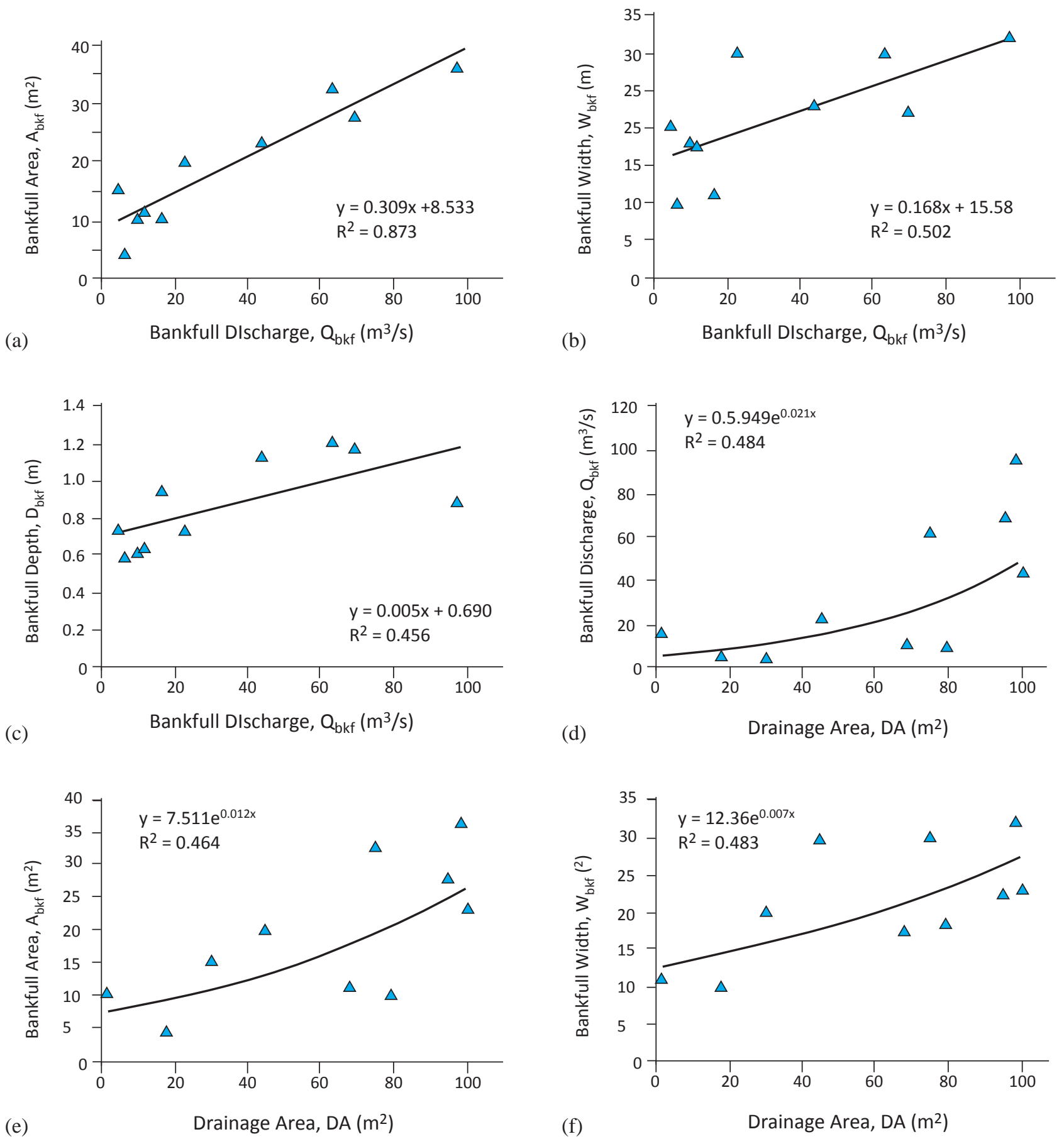

Fig. 7. Hydraulic geometry relations for the Malekhu Khola: (a) Area hydraulic geometry relation, and (b)Width hydraulic geometry relation, (c) Depth hydraulic geometry relation, (d) Discharge regional curve, (e) Area regional curve, and (f) Width regional curve

When the sediment load, i.e., sediment transport capacity in Tonnes/day is plotted against bankfull width (Fig. 8a), all the bedload equations exhibit exponential function of increase of sediment transport capacity of the Malekhu River with increased bankfull width. The bankfull discharge versus sediment transport capacity curve shows linear function of correlation (Fig. 8b), in which, as discharge increases the sediment transport capacity also tends to increase for the Malekhu Khola. 
Table 11: Calculated rate of bedload in weight per unit time Qs in Tonnes/day using different relations along the Malekhu Khola

\begin{tabular}{lccc}
\hline & \multicolumn{3}{c}{ Bedload transport (Tonnes/day) } \\
Transects & $\begin{array}{c}\text { Einstein and Brown } \\
(1942-1950)\end{array}$ & $\begin{array}{l}\text { Bonnefille } \\
(1963)\end{array}$ & $\begin{array}{l}\text { Hassanzadeh } \\
(2007)\end{array}$ \\
\hline T1 & $7857 \times 10^{3}$ & $6805 \times 10^{3}$ & $7101 \times 10^{3}$ \\
T2 & $290 \times 10^{3}$ & $495 \times 10^{3}$ & $447 \times 10^{3}$ \\
T3 & $9598 \times 10^{3}$ & $5503 \times 10^{3}$ & $6554 \times 10^{3}$ \\
T4 & $10233 \times 10^{3}$ & $8249 \times 103$ & $8796 \times 10^{3}$ \\
T5 & $3861 \times 10^{3}$ & $3453 \times 10^{3}$ & $3569 \times 10^{3}$ \\
T6 & $6816 \times 10^{3}$ & $6052 \times 10^{3}$ & $6270 \times 10^{3}$ \\
T7 & $938 \times 10^{3}$ & $1166 \times 10^{3}$ & $1106 \times 10^{3}$ \\
T8 & $8903 \times 10^{3}$ & $6910 \times 10^{3}$ & $7456 \times 10^{3}$ \\
T9 & $26657 \times 10^{3}$ & $17274 \times 10^{3}$ & $19747 \times 10^{3}$ \\
T10 & $2129 \times 10^{3}$ & $2324 \times 10^{3}$ & $2275 \times 10^{3}$ \\
\hline
\end{tabular}

\section{Suspended Sediment Load}

Sediment discharge or sediment load in the channel was calculated by multiplying the main concentration of water at each cross-section by the average discharge. The results of suspended sediment concentration at ten different locations along the Malekhu Khola (Table 12) show that the SSC increases from upstream to downstream. SSC at T9 is exceptionally high (193.78 $\mathrm{mg} / \mathrm{L})$ compared to the least value at $\mathrm{T} 8(20.47 \mathrm{mg} / \mathrm{L})$. The major tributaries of Malekhu Khola has contributed significant amount of suspended sediment to the river system. The Aap Khola is the major tributary contributing maximum suspended sediment which is $997.23 \mathrm{mg} / \mathrm{L}$. The suspended sediment measurement given here is of one time measurement of a particular

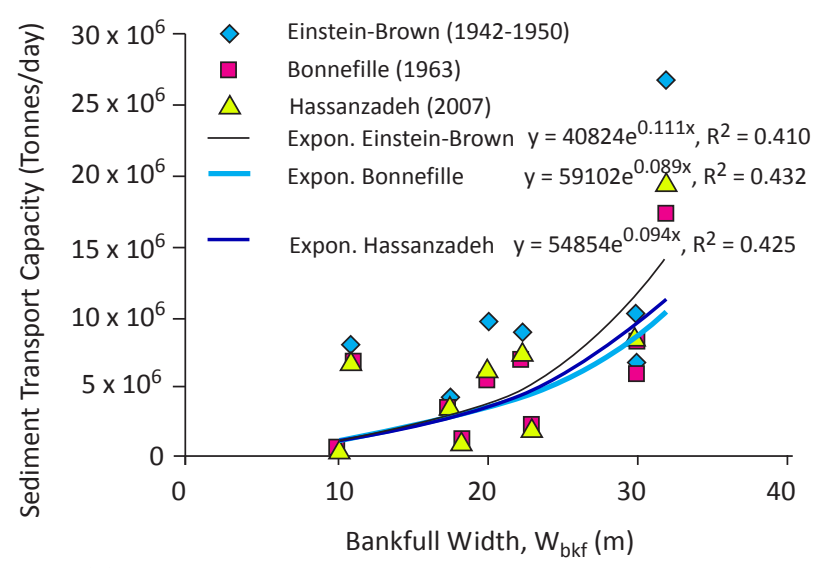

(a)

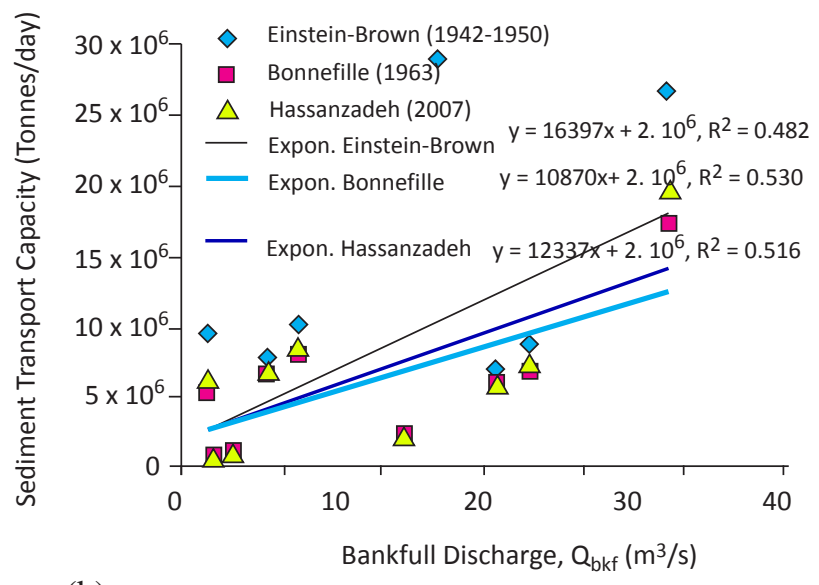

(b)

Fig. 8 (a) Sediment transport capacity vs channel width, and (b) Bankfull discharge versus sediment transport capacity of the Malekhu Khola

Table 12: Suspended sediment discharge of the Malekhu Khola

\begin{tabular}{ccccc}
\hline Transect & SSC $(\mathrm{mg} / \mathrm{L})$ & $\mathrm{SSC}\left(\mathrm{Kg} / \mathrm{m}^{3}\right)$ & $\begin{array}{c}\text { Suspended Sediment } \\
\text { Discharge }(\mathrm{kg} / \mathrm{s})\end{array}$ & $\begin{array}{c}\text { Suspended Sediment } \\
\text { Discharge (Tonnes/day) }\end{array}$ \\
\hline T1 & 38.67 & 0.04 & 0.64 & 55 \\
T2 & 78.33 & 0.08 & 0.47 & 41 \\
T3 & 40.27 & 0.04 & 0.19 & 16 \\
T4 & 106.33 & 0.11 & 2.43 & 210 \\
T5 & 40.42 & 0.04 & 0.47 & 41 \\
T6 & 84.84 & 0.08 & 5.32 & 460 \\
T7 & 52.00 & 0.05 & 0.51 & 44 \\
T8 & 20.47 & 0.02 & 1.42 & 123 \\
T9 & 193.78 & 0.19 & 18.8 & 253 \\
T10 & 66.32 & 0.07 & 2.93 & \\
\hline
\end{tabular}




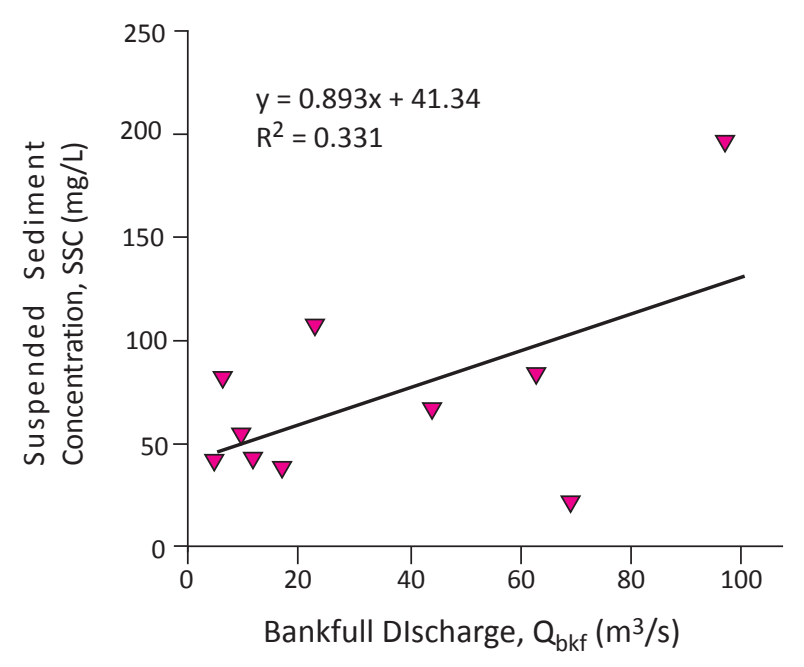

Fig. 9 Sediment rating curve of the Malekhu Khola

season (post monsoon). In this season the sediment rating curve, i.e., the discharge versus suspended sediment concentration (Fig. 9), shows positive but weak correlation due to anomalous result in transect $\mathrm{T} 8$.

\section{CONCLUSIONS}

The Malekhu Khola is a 6th order stream which is contributed by three major tributaries as 5th order Khani Khola, 4th order Dumling Khola and another 4th order Aap Khola. The majority of the subwatersheds are in mature stage while the big subwatersheds such as those of the Khani Khola and the Dumlin Khola are in relatively old stage. The Malekhu Khola is classified as A4-, B4- and C4- type streams, and is a gravel bed stream. It shows eroding tendency at $1.2 \mathrm{~km}, 16.6 \mathrm{~km}$ and $20 \mathrm{~km}$ from the origin, and has enough competency to move larger particles $\left(\mathrm{d}_{50}\right)$ mostly from the Transect $\mathrm{T} 5$ towards the downstream segments. The stream is not competent to carry $\mathrm{d}_{10}$-sized particles at bankfull condition, and therefore these oversized particles are transported only during debris flow.

Sorting of the channel sediments of the Malekhu Khola is extremely poor to moderately poor. The median grain size slightly increases downstream. Sorting and size of channel sediment has been affected by the human influences, i.e., extraction of riverbed materials for construction aggregates.

The hydraulic geometry relations show moderate degree of correlations. The better and positive linear correlation is found in bankfull cross-sectional area versus bankfull discharge plot. The regional curves showing relationships of hydraulic parameters with the drainage basin area show moderate degree of positive correlation. The hydraulic geometry relations and regional curves are found to be very much influenced and the resulting degree of correlations is low to moderate because of river mining activities.

Bedload transport load calculated ranges between $290 \times 10^{3}$ and $26657 \times 10^{3}$ Tonnes/day. Bedload transport capacity versus bankfull width and bankfull discharge plots also show moderate degree of correlations. Bedload transport rate depends on distance, water discharge, bankfull depth, bankfull width, bankfull velocity and gradient.

Suspended sediment discharge ranges from 55 to 1624 Tonnes/day. The suspended sediment discharge is about $0.02 \%$ of the bedload transport, and thus the Malekhu Khola is a bedload river. The sediment rating curve shows poor correlation, and though suspended sediment concentration tends to increase with increased discharge it is much influenced by river mining activities in the downstream segments of the Malekhu Khola.

It is recommended to establish a gauge station to better understand and monitor the sediment transport and discharge of the Malekhu Khola.

\section{REFERENCES}

ASTM D3977-97(2002), Standard Test Methods for Determining Sediment Concentration in Water Samples, ASTM International, West Conshohocken, PA, 1997, D O I : $10.1520 / \mathrm{D} 3977$ - $97 \mathrm{R} 02$ https://doi.org/10.1520/D3977-97R02

Bagnold, R.A., 1966. An Approach to the Sediment Transport Problems from General Physics, U.S. Geol. Survey, Prof. Paper 422-I, 37p.

Bonnefille, R., 1963. Essais de synthese des lois de debut d'entrainment des sediment sours l'action d'un courant en regime uniform. Bull. Du CREC, no. 5, Chatou.

Brookes, A. 1990. Restoration and enhancement of engineered river channels: some European experiences. Regulated Rivers: Research and Management, v. 5, no.1, pp. 45-56. https://doi.org/10.1002/rrr.3450050105

Brown, C.B., 1950. Sediment Transportation. Chapter XII Engineering Hydraulics. H. Rouse. New York, N.Y, John 
Wiley and Sons.

Chow, V.T., 1959. Open channel hydraulic. McGraw-Hill, Inc. New York.

Cowan, W. L. (1956). "Estimating hydraulic roughness coefficients," Agricultural Engineering, v. 37, pp. 473-475.

Du Boys M. P., 1879. Le Rhone et les Rivieres a Lit affouillable. Mem.Doc., Ann. Pont et Chaussees, ser. 5, $18 \mathrm{p}$.

Einstein, H.A., 1942, Formulae for transportation of bedload, Trans. ASCE, 107, pp. 561-577.

Einstein, H.A., 1950. The bed-load function for sediment transportation in open channel flows. Technical Bulletin, No. 1026, U.S. Dep. of Agriculture, Washington, D.C.

Folk, R. L. and Ward, W. C., 1957. Brazons River bar: a study in the significance of grain size parameters. Journal of Sedimentary Petrology, v. 27, pp. 3-26. https://doi.org/10.1306/74D70646-2B21-11D78648000102C1865D

Hassanzadeh, Y., 2007. "Evaluation of Sediment Load in a Natural River" Journal of Water International, v. 32, $\mathrm{N}$ o . 1, p p $145-154$. https://doi.org/10.1080/02508060708691971

Garg, S.K. 1983. Geology- the Science of the earth. Khanna Publishers, New Delhi.

Pike, R.J. and Wilson, S.E. 1971. Elevation-relief ratio, hypsometric integral and geomorphic area-altitude analysis. Geological Soc. Am. Bull., v. 82, pp. 1079-1084. h t t p s : / / d o i.org/10.1130/00016 7606(1971)82[1079:ERHIAG]2.0.CO;2

Poleto, C., Bortoluzzi, E.C., Charlesworth, S.M. and Merten, G.H. Urban sediment particle size and pollutants in Southern Brazil. J. Soils Sediments, v. 9, pp. 317-327, 2009. https://doi.org/10.1007/s11368-009-0102-0

Roberts, M.J., Marsh R. New, A.L., AND Wood, R.A., 1996, Anintercomparison of a Bryan-Cox-type ocean model and on isopycnic ocean model, Part I: The superior gyre and high latitude processes.

Rosgen, D.L., 1994. A Classification of natural rivers. Catenna, v. 22, pp. 169-199. https://doi.org/10.1016/03418162(94)90001-9

Shrestha, P. and Tamrakar, N.K., 2012. Morphology and classification of the main stem Bagmati River, Central Nepal. Bulletin of the Department of Geology, Tribhuvan University, Kathmandu, Nepal, v. 15, pp. 23-34. DOI: http://dx.doi.org/10.3126/bdg.v15i0.7415

Singh, J. L., Tamrakar N. K., 2013. Rock Mass Rating and Geological Strength Index of rock masses of ThopalMalekhu River areas, Central Nepal Lesser Himalaya. Bulletin of the Department of Geology, Kathmandu, $\mathrm{Nepal,} \quad \mathrm{v} .16, \quad \mathrm{p} \mathrm{p} .29-42$. https://doi.org/10.3126/bdg.v16i0.8882

Singh, O., and Sarangi, A., 2009. Hypsometric analysis of the lesser Himalayan watersheds using geographical information system. Indian Journal. Soil Cons., v.36, no. 3, pp.148-154.

Stocklin, J. 1980. Geology of Nepal and its regional frame. J. geol. Soc. London. v. 137, 1980, pp. 1-34. https://doi.org/10.1144/gsjgs.137.1.0001

Stocklin, J. And Bhattarai, K.D. (1978).Geology of Kathmandu area and Central Mahabharat Range, Nepal Himlaya. HMG Nepal/ UNDP rep.

Strahler, AN. 1952. Hypsometric (area-altitude) analysis of erosional topography. Geologic. Soc. Am. Bull., v. 63, pp. 1117-1141. https://doi.org/10.1130/00167606(1952)63[1117:HAAOET]2.0.CO;2

Strahler, A.N., 1957. Quantitative analysis of watershed geometry. Trans-American Geophysical Union, v. 38, pp. 913-920. https://doi.org/10.1029/TR038i006p00913

Strahler, A.N., 1969. Physical Geography. 3rd edition, John Willey and Sons, Inc. New York.

Tamrakar, N.K. and Shrestha, M.B., 2008. Relationship between fluvial clastic sediment and source rock abundance in Rapti River Basin of Central Nepal Himalaya.Boletin de Geologia, v. 30, no. 1, pp. 63-75.

Vanoni, V.A., 1984."Fifty Years of Sedimentation" Journal of Hydraulic Engineering, Vol. 110, No. 8 ASCE. https ://doi.org/10.1061/( A S CE) 0733 9429(1984)110:8(1021)

Wolman, M.G., 1954. A method of sampling coarse river bed material. Trans. American Geophysical Union, v. $\quad 35, \quad \mathrm{p} \mathrm{p} \quad 951-956$. https://doi.org/10.1029/TR035i006p00951

Wilcock, P. R., 2001; Toward a practical method for estimating sediment-transport rates in gravel-bed rivers. Earth Surface Process. Landforms, v. 26, pp. 1395-1408. https://doi.org/10.1002/esp.301

Yalin, M.S., 1963. An Expression for Bed Load Transportation. ASCE 89, HY3.

Yalin, M.S., 1972. Mechanics of SEdiment Transport, Pergamon Press.

Yang, C.T., 1972. Unit Stream Power and Sediment Transport. Proc. ASCE, 98, HY10, pp. 1805-1826.

Yang, C.T., 1973. Incipient Motion and Sediment Transport. Proc. ASCE99, HY10, pp. 1679-1704. 